\title{
Effects of different dietary n-6/n-3 polyunsaturated fatty acid ratios on boar reproduction
}

\author{
Yan Lin ${ }^{1 * \dagger}$, Xu Cheng ${ }^{1 \dagger}$, Jiude Mao², De Wu', Bo Ren ${ }^{1}$, Sheng-Yu Xu', Zheng-Feng Fang ${ }^{1}$, Lian-Qiang Che', \\ Cai-Mei $\mathrm{Wu}^{1}$ and Jian $\mathrm{Li}^{1}$
}

\begin{abstract}
Background: N-3 and N-6 polyunsaturated fatty acids are widely used in reproduction, yet few studies have addressed the effects of dietary n-6/n-3 ratios on boar reproduction. The present study aimed to determine the effects of different dietary $n-6 / n-3$ ratios on the reproductive performance ofn breeding boars. Thirty-two boars with body weights of $15.0 \pm 1.4 \mathrm{~kg}$ were divided into four treatments $(C, T 1, T 2, T 3)$ and fed diets with different n-6/n-3 fatty acid ratios (29.06:1, 20.07:1, 1:1, 1:17.96, respectively) for 174 days.

Results: The highest testis index was observed for treatment T2. Sperm density and total sperm number per ejaculate in the $\mathrm{T} 2$ treatment were significantly higher than those in all other treatments, whereas the sperm deformity rate was the lowest. Interestingly, the fatty acid compositions and ratios of sperm were consistent with dietary treatments. Acid phosphatase and fructose concentration of seminal plasma, and the total superoxide dismutase and glutathione peroxidase of sperm in T2 were higher than those in other treatments. The concentration of testosterone and prostaglandin E2 increased in boars fed on diets supplemented with fatty acids as compared with boars subjected to the $C$ grouptreatment, reaching a peak at $n-6 / n-3$ fatty acid ratios of 1:1. Furthermore, higher expression of $\Delta^{6}$-fatty acid desaturase and peroxisome proliferator activated receptor-a in spermatozoa of the T2 treatment were observed, indicating more vigorous metabolism and intensive hormonal regulation.
\end{abstract}

Conclusions: Our data suggest that the ideal $n-6 / n-3$ ratio in the diet of breeding boars is $1: 1$, and proper balancing of $\mathrm{n}-6 / \mathrm{n}-3$ fatty acids plays an important role in male reproduction.

Keywords: $\mathrm{n}-3$ fatty acids, n-6 fatty acids, Ratio, Boar, Reproduction

\section{Background}

Previous reports have revealed that the fatty acid content of spermatozoa in bulls, boars, rabbits, and humans are very high and has a unique function [1]. Intake of different types and sources of polyunsaturated fatty acids (PUFA) has been shown to change the fatty acid composition of animal sperm and affect sperm quality [2-4]. In fact, researchers have discovered that the male sperm quality can be affected by the pathway of PUFA

\footnotetext{
* Correspondence: linyan936@163.com

${ }^{\dagger}$ Equal contributors

'Key Laboratory for Animal Disease Resistance Nutrition of the Ministry of Education of China, Institute of Animal Nutrition, Sichuan Agricultural University, Ya'an 625001, China

Full list of author information is available at the end of the article
}

metabolism [5], oxidative stress [6], hormone levels, and physiological function of the epididymis $[7,8]$.

The few studies published to-date regarding the effects of PUFA on human and animal male reproduction have reported divergent findings. Fish oil (rich in n-3 PUFA) has been shown to alter sperm structure and penetration resistance, and to increase sperm number [9] and antioxidant capacity [10]. However, some studies report no effect of fish oil on sperm quality [11, 12]. Mohammad et al. $[13,14]$ reported that the consumption of unsaturated fatty acids improved sperm antioxidant capacity of infertile men. Corn oil (rich in n-6 PUFA) and Vitamin E supplements increased the semen volume and sperm antioxidant properties [15]. Different oils have different fatty acid compositions, and we hypothesize that the 
reason for the above noted inconsistencies may be different dietary n-6/n-3 PUFA ratios; assuming no differences in fatty acid level. However, relevant information on the effects of PUFA ratios on male animals is rare. Castellano et al. [16] found that the fatty acid composition of boar testis changed in a variety of phospholipids hat after fish oil supplement, and the ratio of $n-6 / n-3$ PUFA in sphingomyelin was reduced. On the other hand, adding tuna oil to the diet of the boars changed the fatty acid composition of sperm and seminal plasma, and the $n-6 / n-3$ ratios in sperm and seminal plasma were reported as 2.26:1 and 0.997:1, respectively [17]. Furthermore, we found that sperm density, vitality and sperm morphological integrity in rats, were greatly improved when the dietary $n-6 / n-3$ ratio of PUFA was 1.52:1 [18]. Thus, we hypothesized that different proportions of PUFA would affect the reproductive performance of boars. The objective of the present study was to determine the effects of different ratios of n-6/n-3 PUFA on testis development and reproductive performance in breeding boars.

\section{Methods}

\section{Experimental design}

All experimental protocols were approved by the Biosafety and Animal Care and Use Committees at Sichuan Agriculture University. Thirty-two boars with an average body weight of $15.0 \pm 1.4 \mathrm{~kg}$ were randomly assigned to 4 groups: 3 treatment groups (T1, T2 and T3) fed with different ratios of dietary sunflower oil and fish oil, and a control group (C). Diets were formulated based on NRC recommendations (2012) [19] for breeding boars according to body weight. The fatty acid compositions of the oils and the basal diet $(\mathrm{C}$, without oil supplementation) are presented in Table 1, and the fatty acid compositions of all diets are presented in Table 2. The onset of puberty (sperm production) occurs at 120-180 days in conventional boars. During the present study, boars were fed ad-lib from 1 to 18 weeks, and subsequently fed restricted diets. Boars were housed individually at an ambient temperature between 18 and $22{ }^{\circ} \mathrm{C}$, and had free access to water.

\section{Testicular index measurement}

Boars were weighed at 4,10 , and 18 weeks, and then the length and width of boar testis were measured. The testicular longitudinal maximum length and horizontal maximum width between two endpoints were measured using a vernier caliper. Testicular volume was calculated using the formula [19]:

$$
\text { volume }=\frac{4}{3} \pi \times\left(\frac{1}{2} \text { length }\right) \times\left(\frac{1}{2} \text { width }\right)^{2} \times 2
$$

Testis index was expressed as the percentage of average boar testicular volume divided by body weight $(\mathrm{kg})$.

\section{Lipid analysis in diet and spermatozoa}

The fatty acid compositions of diets (oils and diet) were evaluated using Shimadzu GC-14B gas chromatography

Table 1 Composition of the control diets

\begin{tabular}{|c|c|c|c|c|c|}
\hline Items & $15-40 \mathrm{~kg}$ & $40-60$ kg & $60-80 \mathrm{~kg}$ & 80-100 kg & $100-130 \mathrm{~kg}$ \\
\hline Corn & 65.07 & 67.06 & 67.37 & 70.17 & 70.14 \\
\hline Soybean meal & 20.00 & 20.00 & 23.50 & 21.00 & 21.50 \\
\hline Wheat bran & 3.00 & 3.00 & 4.00 & 4.00 & 4.00 \\
\hline Fish meal & 4.50 & 3.50 & 1.00 & 1.00 & 1.00 \\
\hline Yeast protein & 3.00 & 2.50 & 0.00 & 0.00 & 0.00 \\
\hline L-lysine & 0.46 & 0.37 & 0.38 & 0.29 & 0.12 \\
\hline D-Methionine & 0.07 & 0.05 & 0.05 & 0.02 & 0.00 \\
\hline L-Threonine & 0.15 & 0.08 & 0.14 & 0.11 & 0.04 \\
\hline Calcium carbonate & 0.29 & 0.33 & 0.35 & 0.38 & 0.41 \\
\hline Dicalcium phosphate & 2.05 & 1.90 & 2.05 & 1.87 & 1.63 \\
\hline Chloride choline & 0.15 & 0.15 & 0.15 & 0.15 & 0.15 \\
\hline Salt & 0.25 & 0.25 & 0.20 & 0.20 & 0.20 \\
\hline Saleratus & 0.20 & 0.00 & 0.00 & 0.00 & 0.00 \\
\hline Vitamin premix ${ }^{a}$ & 0.21 & 0.21 & 0.21 & 0.21 & 0.21 \\
\hline Mineral premix ${ }^{\mathrm{b}}$ & 0.60 & 0.60 & 0.60 & 0.60 & 0.60 \\
\hline Total & 100 & 100 & 100 & 100 & 100 \\
\hline
\end{tabular}

${ }^{a}$ Vitamin premix are changed during the boars growth according to the NRC(2012), and vitamin E is 100 IU/kg VE as dl-a-tocopheryl acetate in all diets

${ }^{b}$ Mineral premix are changed during the boars growth according to the NRC(2012) 
Table 2 Fatty acid composition in diets ${ }^{\text {a }}$

\begin{tabular}{lllll}
\hline Fatty acid & C & T1 & T2 & T3 \\
\hline Fish Oil (\%) & 0 & 0.2 & 2 & 3 \\
Sunflower oil (\%) & 0 & 2.8 & 1 & 0 \\
Myristic (C14:0) & 0.7 & 0.6 & 4.7 & 7.0 \\
Palmitic (C16:0) & 13.2 & 7.2 & 14.9 & 19.3 \\
Palmitoleic (C16:1) & 0.9 & 0.7 & 5.2 & 7.4 \\
Stearic (C18:0) & 2.1 & 4.9 & 4.2 & 3.7 \\
Oleic (C18:1) & 29.1 & 28.6 & 17.9 & 11.9 \\
Linoleic (C18:2) & 49.4 & 52.1 & 19.9 & 1.6 \\
Linolenic (C18:3) & 1.7 & 0.5 & 1.2 & 1.7 \\
Eicosanoic (C20:0) & 0.6 & 0.4 & 0.8 & 1.0 \\
Gondoic (C20:1) & 0.4 & 0.6 & 1.9 & 2.7 \\
Eicosapentaenoic acid (C20:5) & - & 0.8 & 7.2 & 10.8 \\
Erurcic acid (C22:1) & - & 0.8 & 2.4 & 3.3 \\
Docosahexaenoic (C22:6) & - & 1.3 & 11.4 & 17.2 \\
Other fatty acids & 1.9 & 1.0 & 7.9 & 11.9 \\
Total n-3 PUFA & 1.7 & 2.6 & 19.9 & 29.6 \\
Total n-6 PUFA & 49.4 & 52.1 & 19.9 & 1.7 \\
Ratio of n-6/n-3 & $29: 1$ & $20: 1$ & $1: 1$ & $1: 18$ \\
\hline aC, & & & &
\end{tabular}

${ }^{a} \mathrm{C}$, the control group; $\mathrm{T} 1$, the $0.2 \%$ fish oil group; $\mathrm{T} 2$, the $2 \%$ fish oil group; $\mathrm{T} 3$, the $3 \%$ fish oil group. Data expressed as a percentage of total fat acid on the weight basis. Values are means $(n=4)$. "-": at or below $0.5 \%$ of total fatty acids undetected

apparatus (Shimadzu Co., Ltd., Kyoto, Japan) in the Food Quality Testing Center (Cheng du, Sichuan, China) [20]. The fatty acid compositions of the spermatozoa were evaluated by HP6890 GC-FID gas chromatography apparatus (Agilent Technologies, Palo Alto, USA) in the Analysis and Testing Center of China Agricultural University according to the method described by Am-in et al. [21], and the composition of samples calculated based on the standard curve. Each fatty acid proportion was expressed as a percentage of the total fatty acids.

\section{Semen collection and analysis}

Boars were trained to mount a dummy for semen collection at 7 months age. After 4 weeks training period, semen was collected twice per week for 4 weeks using the gloved hand technique. The ejaculation duration and reaction time were recorded during each collection, and 4 layers of sterile gauze was used to filter the semen. The gel-free volume of semen, sperm motility, $\mathrm{pH}$ and sperm viability were evaluated according to the methods of the world health organization (WHO) and those described by Kaeoket et al. [22, 23]. More than 200 spermatozoa and 3 fields under 10x microscope magnification (Olympus, Japan) were assessed for evaluation of sperm motility. Moreover, the sportive and linear motion sperm in each field were recorded using a counter. Sperm density, expressed as the number of spermatozoa $\times 10^{8}$ cells $/ \mathrm{ml}$, was determined using a Makler counting chamber (Sefi-Medical Instruments, Haifa, Israel) [24] for each ejaculate. Sperm abnormalities included those classified as head shape, head size and head number anomalies, as well as tail shape, tail length and tail number anomalies. The gentian violet alcohol solution staining method was used with sperm smear staining, and a minimum of 3 replicates of 100 spermatozoa were counted at 200x magnification using light microscopes and expressed as the sperm deformity rate [11].

Semen samples of each boar collected during the $2^{\text {nd }}$ and $4^{\text {th }}$ week following the training period were immediately centrifuged (Biofuge Heraeus Primor, USA) at $1000 \mathrm{~g}$ for $15 \mathrm{~min}$. Seminal plasma was stored at $-20{ }^{\circ} \mathrm{C}$ for future analysis, and semen was gently washed with phosphate buffered saline (PBS), and stored in $200 \mu \mathrm{l}$ tubes at $-80{ }^{\circ} \mathrm{C}$ for fatty acid and antioxidant capacity analyses.

\section{Blood sample collection and hormone assay}

Blood for serum samples was collected during the $2^{\text {nd }}$ and $24^{\text {th }}$ week of age by venipuncture of the jugular vein, and centrifuged for $15 \mathrm{~min}$ at $4{ }^{\circ} \mathrm{C}$ and $3500 \mathrm{~g} / \mathrm{min}$. Serum was stored at $-20{ }^{\circ} \mathrm{C}$ for hormone analysis. The concentrations of testosterone $(\mathrm{T})$ and prostaglandins $\mathrm{E}_{2}$ (PGE2) were determined using the an ELISA kit (Immunotech, R\&D, USA). Absorbance was measured at $450 \mathrm{~nm}$ using an automatic enzyme standard instrument (Thermo Electron Corporation, Varioskan ${ }^{\mathrm{Tn}}$, Waltham, MA, USA). A standard curve was constructed based on the absorbance of standard samples, and each sample hormone concentration was calculated and expressed as $\mathrm{ng} / \mathrm{ml}$.

\section{Anti-oxidant capacity measurement}

The total superoxide dismutase (T-SOD), glutathione peroxidase (GSH-Px) activity and total anti-oxidative capacity (T-AOC) of spermatozoa were determined using a commercially available kit (Jiancheng Bioengineering Institute, Nanjing, China), following the manufacturer's protocols. Before the assays, the sperm was homogenized by ultrasonic disintegrator (JY96-II, Shanghai, China) in PBS solution and centrifuged at $1000 \mathrm{~g}$ for $10 \mathrm{~min}$ at $4{ }^{\circ} \mathrm{C}$. The supernatant was used for the analysis. One unit of T-SOD activity was defined as the amount of sample protein capable of inhibiting the reduction of nitro blue tetrazolium (NBT) by $50 \%$ of maximum inhibition, whereby 1 unit of GSH-Px was defined as the amount of enzyme necessary to oxidize $1 \mu \mathrm{mol} / \mathrm{NADPH} / \mathrm{min}$ at $\mathrm{pH} 7.0$ at $25^{\circ} \mathrm{C}$. The TAOC reflects the enzyme and non-enzyme original antioxidant, which can reduce the ferricion $\left(\mathrm{Fe}^{3+}\right)$ to ferrousion $\left(\mathrm{Fe}^{2+}\right)$; the latter combines with phenanthroline to produce a stable chelate, which can be measured by spectrophotography at $520 \mathrm{~nm}$ wavelength. One unit of TAOC was defined as per milligram of tissue protein 
increasing 0.01 absorbance in $1 \mathrm{~min}$ [25]. Malondialdehyde (MDA) concentrations were quantified using the thiobarbituric acid method, which is based on the reaction of MDA with thiobarbituric acid to form a pink chromogen [26], and MDA concentration was expressed as $\mathrm{nmol} / \mathrm{mg}$ protein.

\section{Analysis of fructose, acid phosphatase and alpha- glucosidase in seminal plasma}

Seminal plasma fructose concentration was measured using the resorcinol colorimetric method [27, 28]. Absorbance values were read at $520 \mathrm{~nm}$ against blanks by UV-1100 spectrophotometer (Meipuda instrument Co., Shanghai, China). A set of fructose standards was prepared and used to generate a standard curve. Seminal plasma acid phosphatase (ACP) was determined using the benzene disodium phosphate method [29], and 1 unit of activity was defined as $100 \mathrm{ml}$ of sample reacting with substrate for $30 \mathrm{~min}$ at $37{ }^{\circ} \mathrm{C}$ to produce $1 \mathrm{mg}$ phenol. Alpha-glucosidase was determined using the glucose oxidase method [30], whereby absorbance was quantified at $505 \mathrm{~nm}$ wave length and 1 unit of activity was defined as per $\mathrm{ml}$ sample producing $1 \mu \mathrm{mol}$ of $\mathrm{D}$-glucose $/ \mathrm{min}$ at $37^{\circ} \mathrm{C}, \mathrm{pH} 6.8$.

\section{RNA extraction and PCR assay}

The total ribose nucleic acid (RNA) of samples was extracted using the Invitrogen trizol reagent kit (Invitrogen, Carlsbad, CA, USA). Spermatozoa were thawed in ice water and mixed with $0.25 \mathrm{ml}$ Rnase-free water in a $1.5 \mathrm{ml}$ tube. $0.75 \mathrm{ml}$ trizol solution was then added to the tube, and the sample was violently oscillated at $25{ }^{\circ} \mathrm{C}$ in a water bath for $5 \mathrm{~min}$ [31]. The remainder of the method was performed according to the manufacturer's instructions. Reverse transcription was carried out with a commercial kit (Takara prime script ${ }^{\mathrm{mi}} \mathrm{RT}$ reagent kit with gDNA eraser, Dalian, China) using a conventional PCR machine (Bio-Rad Peltier Thermal Cycler). Primer design and synthesis of genes (Table 3) were performed by Shanghai Biological Engineering Company, China. Gene expression was determined by fluorescence quantitative reagent (SYBR Premix Ex Taq ${ }^{\text {II }}$, Takara) using fluorescence quantitative PCR (Bio-Rad CFX96 RealTime system c1000 Thermal Cycler). All procedures were carried out following the manufacturer's instructions, and the relative expression levels of genes were normalized with the housekeeping gene, $\beta$-actin.

\section{Statistical analysis}

Data were analyzed using SPSS19.0 statistic software and expressed as mean \pm standard deviation (SD). Data from the study was examined using analysis of variance (ANOVA). Multiple comparisons by Duncan analysis were used to examine statistical differences among treatments. Statistical significance was taken at the $5 \%$ level.

\section{Results}

\section{Growth performance}

The feed intake and weight gain of boars are summarized in Table 4. There were no significant differences in bodyweight between boars at the beginning of the experiment, nor in average body weight gain or food intake. However, a significant difference in testis index was identified between treatments (Fig. 1), with the testis index of T1 and T2 significantly higher than T3 and the C group $(P<0.05)$.

Table 3 The primer sequences of target genes and house-keeping gene

\begin{tabular}{|c|c|c|c|}
\hline Gene & Primer sequences $\left(5^{\prime}-3^{\prime}\right)$ & Product size (bp) & Gene Bank no. \\
\hline \multirow[t]{2}{*}{ FAD6 } & F: GCATCATGCCTACACCAACG & \multirow[t]{2}{*}{150} & \multirow[t]{2}{*}{ NM_001244792 } \\
\hline & R: TCCACCTCTCTCAGCCGCTC & & \\
\hline \multirow[t]{2}{*}{ CPT-1 } & F: ATAGAGACTTCCCTGAGCTGCG & \multirow[t]{2}{*}{102} & \multirow[t]{2}{*}{ AF288789.1 } \\
\hline & R: TCTGCATTTCTTGATCAGCCCT & & \\
\hline \multirow[t]{2}{*}{ SOD-1 } & F: GGCAGAGGTGGAAATGAAGAA & \multirow[t]{2}{*}{107} & \multirow[t]{2}{*}{ GU944822 } \\
\hline & R: CAGACCATGGCATGAGGGAAT & & \\
\hline \multirow[t]{2}{*}{ GPx-4 } & F: GTGTGGTGAAGCGGTACGGT & \multirow[t]{2}{*}{124} & \multirow[t]{2}{*}{ NM_214407 } \\
\hline & R: CAGGTGGAAGGCTCTGAGGG & & \\
\hline \multirow[t]{2}{*}{ PPAR-a } & F: ATAATGCAATTCGATTTGGGC & \multirow[t]{2}{*}{115} & \multirow[t]{2}{*}{ AF175309.1 } \\
\hline & R: AGAGACTTGAGATCTGCGGTCTC & & \\
\hline \multirow[t]{2}{*}{ CYP11A1 } & F: GAGTAGCAGTGGTAGGGGCAG & \multirow[t]{2}{*}{159} & \multirow[t]{2}{*}{ NM_214427.1 } \\
\hline & R: CGAGGGGTITTAGTGGAGATG & & \\
\hline \multirow[t]{2}{*}{ GADPH } & F: CTACAGCAACAGGGTGGTGGA & \multirow[t]{2}{*}{181} & \multirow[t]{2}{*}{ NM_001206359.1 } \\
\hline & R: TGGGATGGAAACTGGAAGTCA & & \\
\hline
\end{tabular}


Table 4 Effects of long-chain n-3 fatty acids on the feed intake and body weight gain of boars ${ }^{a}$

\begin{tabular}{lcccc}
\hline Items & \multicolumn{1}{c}{ C } & T1 & T2 & T3 \\
\hline Initial body weight $(\mathrm{kg})$ & $20.9 \pm 0.5$ & $20.1 \pm 1.2$ & $20.1 \pm 1.2$ & $20.0 \pm 1.2$ \\
Final body weight $(\mathrm{kg})$ & $137.8 \pm 7.2$ & $136.8 \pm 3.4$ & $135.8 \pm 3.3$ & $135.0 \pm 5.6$ \\
Weight gain $(\mathrm{kg})$ & $0.74 \pm 0.03$ & $0.79 \pm 0.01$ & $0.78 \pm 0.02$ & $0.79 \pm 0.06$ \\
Food intake $(\mathrm{kg} / \mathrm{d})$ & $2.04 \pm 0.08$ & $1.93 \pm 0.03$ & $1.93 \pm 0.02$ & $1.94 \pm 0.07$ \\
\hline
\end{tabular}

${ }^{a} \mathrm{C}$, the control group; T1, the $0.2 \%$ fish oil group; T2, the $2 \%$ fish oil group; T3, the $3 \%$ fish oil group. Data were expressed as means \pm standard deviation ( $n=8$ )

\section{Fatty acid composition in spermatozoa}

The content of $n-3$ fatty acid in spermatozoa increased with increasing dietary n-3 fatty acid content. The n- 6 and n-3 fatty acid content in spermatozoa of the $C$ group was lower than other treatments (Table $5, P<0.05$ ). The $n-6 / n-$ 3 ratio in T3 boars was significantly lower than in $\mathrm{C}$ and T1 boars.

\section{Semen quality}

As shown in Table 6, the reaction time (ejaculation time) in T2 boars was significantly shorter than other treatment groups $(P<0.05)$. The semen volume of T3 boars was greater than other treatments $(P<0.05)$, with no significant differences identified between $C, \mathrm{~T} 1$ and $\mathrm{T} 2$ treatments. Sperm density and the total sperm number per ejaculation in T2 boars were significantly higher than in other treatments $(P<0.05)$, and sperm deformity rate was significantly lower $(P<0.05)$. However, no significant difference in semen $\mathrm{pH}$, sperm motility and linear motion rate of sperm were identified between treatments.

\section{Seminal plasma biochemistry}

Seminal plasma ACP and fructose concentration in the T2 treatment were significantly higher than all other treatments (Table $7, P<0.05$ ). However, alpha-glucosidase activity decreased with increasing dietary n-3 PUFA content $(P<0.05)$. No obvious difference in MDA level and T-SOD

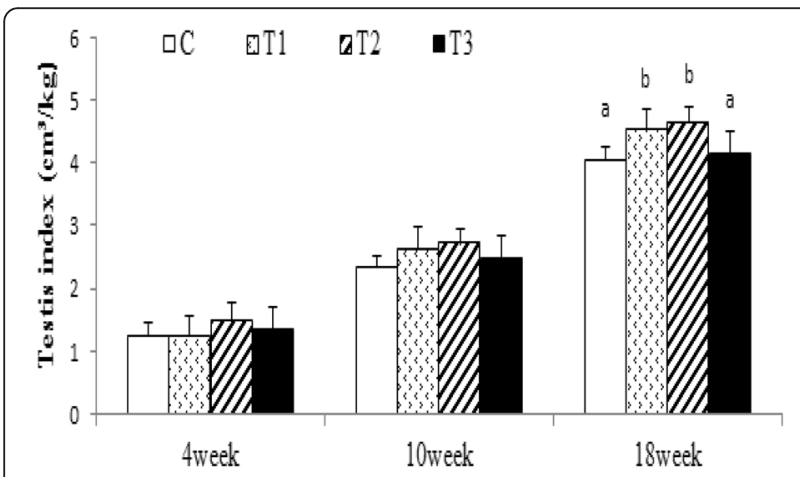

Fig. 1 Effects of different ratios of $n-6 / n-3$ PUFA on the testicular volume index of boars $(n=8)$. Testis index = testis volume $\left(\mathrm{cm}^{3}\right)$ / body weight $(\mathrm{kg})$. Values with different letters indicate a significant difference $(P<0.05)$ activity was apparent in seminal plasma and sperm between treatments (Table 8). GSH-Px activity of seminal plasma in the T3 treatment was significantly higher than in the $\mathrm{C}$ treatment $(P<0.05)$, while sperm GSH-Px activity in the T2 treatment was significantly higher than in the T1 treatment $(P<0.05)$. After dietary supplementation with oil, seminal plasma T-AOC increased, with no significant difference apparent between T1, T2 and T3 treatments. Dietary n-6/n-3 ratios had no significant effect on sperm T-AOC.

\section{Serum hormone}

Compared to the $\mathrm{C}$ group, serum testosterone $(\mathrm{T})$ and $\mathrm{PGE}_{2}$ levels were significantly higher in all oil-supplemented treatments (Table 9), with no significant difference for in $\mathrm{T}$ between them. Interestingly, $\mathrm{PGE}_{2}$ concentration in the T2 treatment was higher than other

Table 5 Effects of long-chain n-3 fatty acids on the composition of spermatozoa (\%) ${ }^{a}$

\begin{tabular}{lllll}
\hline Fatty acids & $\mathrm{C}$ & $\mathrm{T} 1$ & $\mathrm{~T} 2$ & $\mathrm{~T}$ \\
\hline C6:0 & $1.24 \pm 0.15^{\mathrm{b}}$ & $0.96 \pm 0.15^{\mathrm{a}}$ & $1.05 \pm 0.04^{\mathrm{ab}}$ & $1.23 \pm 0.17^{\mathrm{b}}$ \\
C8:0 & $20.0 \pm 0.6^{\mathrm{d}}$ & $15.2 \pm 0.4^{\mathrm{a}}$ & $16.6 \pm 0.3^{\mathrm{b}}$ & $18.1 \pm 0.6^{\mathrm{c}}$ \\
C10:0 & $0.54 \pm 0.06^{\mathrm{b}}$ & $0.38 \pm 0.05^{\mathrm{a}}$ & $0.38 \pm 0.06^{\mathrm{a}}$ & $0.52 \pm 0.05^{\mathrm{b}}$ \\
C12:0 & $0.68 \pm 0.03^{\mathrm{c}}$ & $0.49 \pm 0.09^{\mathrm{ab}}$ & $0.38 \pm 0.09^{\mathrm{a}}$ & $0.52 \pm 0.04^{\mathrm{b}}$ \\
C14:0 & $7.43 \pm 0.22$ & $7.81 \pm 0.41$ & $7.43 \pm 0.25$ & $7.34 \pm 0.51$ \\
C16:0 & $21.4 \pm 0.2^{\mathrm{c}}$ & $22.9 \pm 0.5^{\mathrm{d}}$ & $19.8 \pm 0.5^{\mathrm{b}}$ & $18.4 \pm 0.2^{\mathrm{a}}$ \\
C16:1 & $0.37 \pm 0.04^{\mathrm{b}}$ & $0.30 \pm 0.01^{\mathrm{a}}$ & $0.38 \pm 0.04^{\mathrm{b}}$ & $0.36 \pm 0.02^{\mathrm{ab}}$ \\
C18:0 & $8.55 \pm 0.29^{\mathrm{b}}$ & $10.02 \pm 0.30^{\mathrm{c}}$ & $8.37 \pm 0.34^{\mathrm{b}}$ & $7.27 \pm 0.18^{\mathrm{a}}$ \\
C18:1 & $1.55 \pm 0.06^{\mathrm{b}}$ & $1.70 \pm 0.11^{\mathrm{b}}$ & $1.55 \pm 0.14^{\mathrm{b}}$ & $1.37 \pm 0.07^{\mathrm{a}}$ \\
C18:2n-6 & $2.44 \pm 0.15^{\mathrm{b}}$ & $2.95 \pm 0.22^{\mathrm{d}}$ & $2.70 \pm 0.05^{\mathrm{c}}$ & $2.21 \pm 0.07^{\mathrm{a}}$ \\
C20:0 & $1.32 \pm 0.42^{\mathrm{ab}}$ & $1.34 \pm 0.04^{\mathrm{ab}}$ & $1.67 \pm 0.15^{\mathrm{b}}$ & $1.02 \pm 0.05^{\mathrm{a}}$ \\
C20:3n-6 & $1.01 \pm 0.01^{\mathrm{a}}$ & $1.32 \pm 0.09^{\mathrm{b}}$ & $1.11 \pm 0.25^{\mathrm{b}}$ & $0.82 \pm 0.03^{\mathrm{a}}$ \\
C20:4n-6 & $2.61 \pm 0.12^{\mathrm{b}}$ & $2.79 \pm 0.07^{\mathrm{b}}$ & $2.65 \pm 0.23^{\mathrm{b}}$ & $2.35 \pm 0.16^{\mathrm{a}}$ \\
C22:6n-3 & $29.2 \pm 1.2^{\mathrm{a}}$ & $32.8 \pm 1.5^{\mathrm{b}}$ & $36.0 \pm 0.4^{\mathrm{c}}$ & $37.1 \pm 0.9^{\mathrm{c}}$ \\
n-6 PUFA & $6.01 \pm 0.33^{\mathrm{b}}$ & $7.36 \pm 0.50^{\mathrm{c}}$ & $6.50 \pm 0.43^{\mathrm{b}}$ & $5.35 \pm 0.19^{\mathrm{a}}$ \\
n-3 PUFA & $29.2 \pm 1.2^{\mathrm{a}}$ & $32.8 \pm 1.5^{\mathrm{b}}$ & $36.0 \pm 0.4^{\mathrm{c}}$ & $37.1 \pm 0.9^{\mathrm{c}}$ \\
Total n-6/n-3 & $0.21 \pm 0.01^{\mathrm{c}}$ & $0.23 \pm 0.01^{\mathrm{d}}$ & $0.17 \pm 0.01^{\mathrm{b}}$ & $0.14 \pm 0.01^{\mathrm{a}}$ \\
\hline
\end{tabular}

${ }^{a} \mathrm{C}$, the control group; $\mathrm{T} 1$, the $0.2 \%$ fish oil group; $\mathrm{T} 2$, the $2 \%$ fish oil group; $\mathrm{T} 3$, the $3 \%$ fish oil group. Data expressed as a percentage of total fat acid on the weight basis, and data represent means \pm standard deviation $(n=6)$, and values in the same row with different superscript letter means significant difference $(P<0.05)$ 
Table 6 Effects of long-chain n-3 fatty acids on the semen quality of boars ${ }^{\mathrm{a}}$

\begin{tabular}{|c|c|c|c|c|}
\hline Items & $C$ & T1 & $\mathrm{T} 2$ & T3 \\
\hline Reaction time (s) & $25.5 \pm 6.6^{b}$ & $14.9 \pm 3.1^{a}$ & $7.4 \pm 2.3^{a}$ & $8.4 \pm 1.8^{\mathrm{a}}$ \\
\hline Persistent period (s) & $295.2 \pm 52.9$ & $293.0 \pm 33.3$ & $280.2 \pm 19.9$ & $323.4 \pm 74.5$ \\
\hline Semen volume (ml) & $166.4 \pm 34.9^{\mathrm{a}}$ & $163.3 \pm 13.6^{a}$ & $201.6 \pm 18.9^{\mathrm{ab}}$ & $219.9 \pm 51.7^{\mathrm{b}}$ \\
\hline Sperm motility (\%) & $76.1 \pm 1.9$ & $76.8 \pm 2.9$ & $77.5 \pm 4.6$ & $72.5 \pm 3.6$ \\
\hline Sperm viability (\%) & $79.6 \pm 4.5$ & $82.2 \pm 2.4$ & $80.2 \pm 6.3$ & $78.7 \pm 3.7$ \\
\hline Sperm density $\left(\times 10^{8} \mathrm{spz} / \mathrm{ml}\right)$ & $2.31 \pm 0.24^{\mathrm{a}}$ & $2.80 \pm 0.18^{b}$ & $2.96 \pm 0.23^{b}$ & $2.20 \pm 0.48^{\mathrm{a}}$ \\
\hline Deformity ratio (\%) & $8.64 \pm 0.98^{c}$ & $4.39 \pm 0.74^{\mathrm{a}}$ & $3.65 \pm 0.73^{\mathrm{a}}$ & $6.34 \pm 1.10^{b}$ \\
\hline $\mathrm{pH}$ & $6.42 \pm 0.21$ & $6.55 \pm 0.12$ & $6.53 \pm 0.36$ & $6.68 \pm 0.44$ \\
\hline Sperm number of each ejaculate each ejaculation & $346.6 \pm 67.8^{\mathrm{a}}$ & $416.5 \pm 51.2^{\mathrm{a}}$ & $539.3 \pm 25.3^{b}$ & $423.4 \pm 32.6^{\mathrm{a}}$ \\
\hline
\end{tabular}

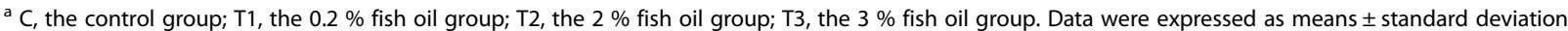
$(n=8)$, and means on the same row with different superscripts were different significantly $(P<0.05)$

groups $(P<0.05)$, but no significant difference was observed between T1 and T3 treatments.

\section{Gene expression}

$\Delta 6$-Fatty acid desaturase (FAD6) and carnitine palmitoyl transferase-1 (CPT-1) are the genes involved in fatty acid metabolism. Results showed significantly higher FAD6 gene expression in the T2 treatment as compared to all other treatments (Fig. 2, $P<0.05$ ), and significantly increased CPT-1 gene expression in T1 and T3 treatments as compared to the $\mathrm{C}$ treatment $(P<0.05)$. mRNA levels of SOD-1 and GPx-4 in the T3 treatment, which are related to oxidative stress, were lower than observed for other treatments $(P<0.05)$. Furthermore, expression of the peroxidase proliferation activated receptor $\alpha($ PPAR- $\alpha)$ and cytochrome P450, family 11 , subfamily A, polypeptide 1 (CYP11A1) were significantly increased in the T2 treatment as compared to all other treatments $(P<0.05)$.

\section{Discussion}

Although there are some reports that fatty acid supplementation may improve the reproduction of human and animal males [9, 32, 33], little research has been done to study the effects of different dietary n-6/n-3 fatty acid ratio before sexual maturity on male reproduction and semen quality. Our data showed that there were no effects on growth performance of breeding boars when they were fed with different $n-6 / n-3$ ratio diets. However, a 1:1 ratio of $n-6$ to $n-3$ in the diet improved the testicular development of boars. External testis dimensions, body weight and sperm characteristics are biomarkers of the reproductive performance in of boars [24]; boars with greater testicular volume may have better libido [34], and the testicular size is the key principle for breeding selection [35].

Semen quality was also significantly affected by the dietary n-6/n-3 PUFA ratio during the present study. It has previously been reported that diets with a $n-6 / n-3$ fatty acid ratio of 1.6:1 could increase the proportion of intact acrosome of the boar's spermatozoa [17]. Oils that are rich in n-3 PUFA also significantly increased sperm density [36] and sperm number [9]. Previously, we reported that the development of testis and the morphological structure of spermatozoa in rats were better with a dietary n-3/n-6 PUFA ratio of 1.52:1 [18]. It was reported that the ratio of $n-6 / n-3$ in boar sperm and seminal plasma was $2.55: 1$ and $3.35: 1$, respectively [37], and that a ratio of $1-4: 1 \mathrm{n}-6 / \mathrm{n}-3$ fatty acids would be beneficial to humans [38]. Additionally, Blesbois et al. [39] found a dietary n-6/n-3 ratio of 10:3 improved the hatch rate of male turkeys. Interestingly, we found that both a high or low dietary n-3/n-6 ratio had adverse effects on sperm motility. As reported by Daraji [40], higher dietary n-6 PUFA (n-6/n-3 = 42.94:1) decreased sperm concentration and the number of normal sperm. Blank et al. [41] reported that ratios of LA:ALA (Linoleic acid: Alpha linolenic acid) lower than 4:1 would have little beneficial effect on docosahexaenoic acid status, suggesting that the proper ratio of dietary $n-6 / n-3$ is important.

It has previously been reported that the composition of sperm fatty acids varies with diet, the content of fatty

Table 7 Effects of long-chain n-3 fatty acids on seminal plasma biochemical of boars ${ }^{\text {a }}$

\begin{tabular}{lllll}
\hline Items & $\mathrm{C}$ & $\mathrm{T} 1$ & $\mathrm{~T}$ & $\mathrm{~T}$ \\
\hline Acid phosphatase $(\mathrm{U} / 100 \mathrm{ml})$ & $157.9 \pm 16.4^{\mathrm{a}}$ & $273.0 \pm 20.1^{\mathrm{b}}$ & $368.7^{\mathrm{a}} \pm 8.8^{\mathrm{c}}$ & $159.1^{\mathrm{a}} \pm 14.2^{\mathrm{a}}$ \\
Fructose $(\mathrm{g} / \mathrm{L})$ & $0.77 \pm 0.09^{\mathrm{b}}$ & $0.59 \pm 0.06^{\mathrm{a}}$ & $1.14 \pm 0.08^{\mathrm{c}}$ & $0.53 \pm 0.05^{\mathrm{a}}$ \\
a-Glucosidase $(\mathrm{U} / \mathrm{ml})$ & $19.7 \pm 1.3^{\mathrm{ab}}$ & $21.9 \pm 2.3^{\mathrm{b}}$ & $20.2 \pm 2.1^{\mathrm{ab}}$ & $16.1 \pm 1.8^{\mathrm{a}}$ \\
\hline
\end{tabular}

${ }^{a} \mathrm{C}$, the control group; $\mathrm{T} 1$, the $0.2 \%$ fish oil group; T2, the $2 \%$ fish oil group; $\mathrm{T} 3$, the $3 \%$ fish oil group. Sample were collected from $2^{\text {nd }}$ and $4^{\text {th }}$ week, and data were the average of two weeks and expressed as means \pm standard deviation $(n=16)$, and values on the same row with different superscripts differ significantly $(P<0.05)$ 
Table 8 Effects of long-chain n-3 fatty acids on the semen antioxidant capacity of boars ${ }^{a}$

\begin{tabular}{|c|c|c|c|c|}
\hline Items & $C$ & $\mathrm{~T} 1$ & $\mathrm{~T} 2$ & T3 \\
\hline \multicolumn{5}{|l|}{ MDA } \\
\hline Seminal plasma (nmol/ml) & $1.67 \pm 0.25$ & $1.91 \pm 0.34$ & $1.77 \pm 0.31$ & $1.84 \pm 0.15$ \\
\hline Sperm (nmol/mg prot) & $3.40 \pm 0.32$ & $3.56 \pm 0.38$ & $3.38 \pm 0.38$ & $3.38 \pm 0.22$ \\
\hline \multicolumn{5}{|l|}{ T-SOD } \\
\hline Seminal plasma (U/ml) & $21.3 \pm 0.6$ & $21.3 \pm 2.2$ & $24.4 \pm 2.5$ & $23.1 \pm 4.1$ \\
\hline Sperm (U/mg prot) & $17.8 \pm 2.8$ & $26.0 \pm 4.1$ & $24.6 \pm 2.5$ & $20.7 \pm 3.3$ \\
\hline \multicolumn{5}{|l|}{ GSH-Px } \\
\hline Seminal plasma (U/ml) & $131.9 \pm 11.0^{\mathrm{a}}$ & $139.0 \pm 11.6^{\mathrm{ab}}$ & $144.5 \pm 17.3^{\mathrm{ab}}$ & $158.1 \pm 12.6^{b}$ \\
\hline Sperm (U/mg prot) & $18.5 \pm 1.7^{\mathrm{ab}}$ & $16.1 \pm 3.6^{\mathrm{a}}$ & $24.2 \pm 1.9^{b}$ & $18.1 \pm 3.8^{\mathrm{ab}}$ \\
\hline \multicolumn{5}{|l|}{ T-AOC } \\
\hline Seminal plasma (U/ml) & $0.64 \pm 0.17^{\mathrm{a}}$ & $0.87 \pm 0.16^{b}$ & $0.79 \pm 0.09^{\mathrm{ab}}$ & $0.84 \pm 0.11^{\mathrm{ab}}$ \\
\hline Sperm (U/mg prot) & $5.51 \pm 0.99$ & $5.91 \pm 0.84$ & $5.69 \pm 0.98$ & $5.47 \pm 0.94$ \\
\hline
\end{tabular}

${ }^{a} \mathrm{C}$, the control group; T1, the $0.2 \%$ fish oil group; T2, the $2 \%$ fish oil group; T3, the $3 \%$ fish oil group. Sample were collected from $2^{\text {nd }}$ and $4^{\text {th }}$ week, and data were the average of two weeks and expressed as means \pm standard deviation $(n=16)$, and values within the same row with different superscripts were significantly different $(P<0.05)$. MDA, malondialdehyde; T-SOD, total superoxide dismutase; GSH-Px, glutathione peroxidase; T-AOC, total ant-oxidative capacity

acids in spermatozoa reflects dietary $n-6 / n-3$ fatty acid ratios, and that the different proportion and source of fatty acids are related to sperm cell membrane structure, lipid composition and acrosome fertilization ability [3, 4, 7]. In fact, PUFA can permeate into sperm cell membranes, significantly affecting the scalability of the sperm plasma membrane and enhancing the osmotic resistance of the acrosomal membrane [10]. Moreover, compared with other oils, the PUFA of fish oil is able to significantly affect the proportion of EPA and DHA in adult boar testicles, and significantly alter the fatty acid composition of testis [16]. Such results further support the conclusion that fatty acid composition of spermatozoa is related to dietary fatty acid composition.

Spermatogenesis and metabolism are regulated by hormones [5]. It is known that testosterone and prostaglandin are associated with fatty acids, and arachidonic acid is usually a precursor of prostaglandin synthesis [5, 7]. Unfortunately, there are few reports of the regulation of hormone synthesis by different PUFA ratios. Hormones regulate the development of the reproductive organs and spermatogenesis. Higher serum testosterone and PGE2 concentrations in the T2 treatment during the present study may indicate improved testis development and superior sperm quality. As reported by Castellano [16], fish oils rich in DHA increased the serum testosterone and estradiol levels in boars. For the rat, it was also demonstrated that dietary fatty acid supplementation altered blood steroid levels [42], and that serum hormone level is related to sperm concentration, motility and morphology [43-45]. We therefore speculate that improvement of sperm quality may be regulated by hormone synthesis and secretion associated with different fatty acid compositions in the diet.

Epididymis and accessory sex glands also play an important role in regulating sperm maturation and fertilization capability [27]. In this study, higher ACP and fructose levels were observed in T2 boars, but higher levels of $n-3$ or $n-6$ fatty acid reduced the fructose concentration and alpha-glucosidase activity in the seminal plasma. Currently, few reports exist concerning the n-3/n-6 PUFA regulation of seminal biochemical markers. Biochemical parameters in semen are directly regulated by hormone and proteins in seminal plasma

Table 9 Effects of long-chain n-3 fatty acids on the serum hormone levels of boars ${ }^{a}$

\begin{tabular}{|c|c|c|c|c|}
\hline Items & C & $\mathrm{T} 1$ & $\mathrm{~T} 2$ & T3 \\
\hline \multicolumn{5}{|l|}{ Testostrone } \\
\hline $2^{\text {nd }}$ week (ng /ml) & $7.4 \pm 1.5^{\mathrm{a}}$ & $8.7 \pm 1.3^{\mathrm{ab}}$ & $10.3 \pm 1.7^{b}$ & $8.5 \pm 1.1^{\mathrm{ab}}$ \\
\hline $24^{\text {th }}$ week (ng $\left./ \mathrm{ml}\right)$ & $7.9 \pm 1.7^{\mathrm{a}}$ & $13.8 \pm 1.8^{\mathrm{b}}$ & $15.8 \pm 2.1^{b}$ & $13.4 \pm 2.1^{b}$ \\
\hline \multicolumn{5}{|l|}{$P G E_{2}$} \\
\hline $2^{\text {nd }}$ week (ng /ml) & $188.9 \pm 29.5^{a}$ & $234.7 \pm 21.4^{b}$ & $288.4 \pm 19.8^{c}$ & $253.3 \pm 15.6^{b}$ \\
\hline $24^{\text {th }}$ week ( $\mathrm{ng} / \mathrm{ml}$ ) & $215.5 \pm 27.5^{\mathrm{a}}$ & $267.2 \pm 29.9^{b}$ & $386.9 \pm 18.8^{c}$ & $308.1 \pm 10.2^{b}$ \\
\hline
\end{tabular}

${ }^{a} \mathrm{C}$, the control group; T1, the $0.2 \%$ fish oil group; T2, the $2 \%$ fish oil group; T3, the $3 \%$ fish oil group. Data were expressed as means \pm standard deviation ( $n=$ 8), and means within the same row with different superscripts differ $(P<0.05)$ 


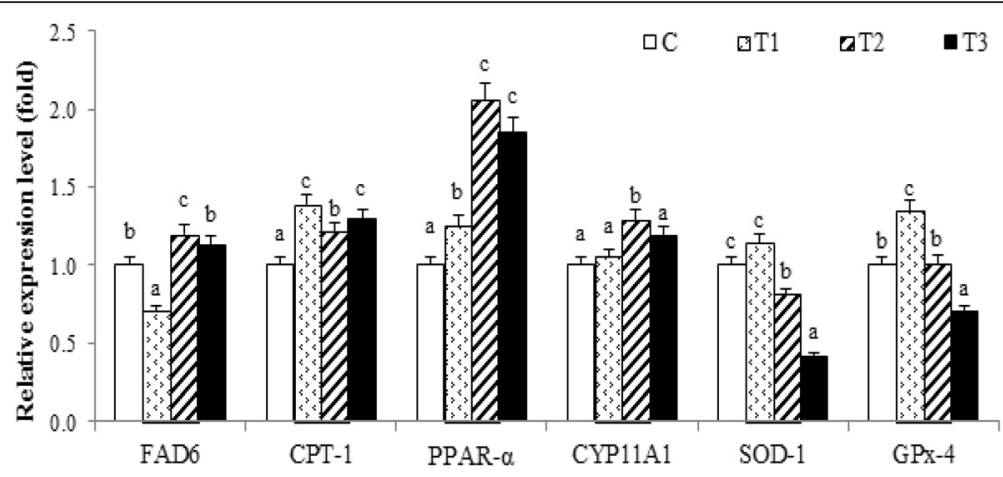

Fig. 2 Effects of different ratios of $n-6 / n-3$ PUFA on the expression of sperm functional genes $(n=4)$. Values with different letters indicate a significant difference $(P<0.05)$. FAD6: $\triangle^{6}$-Fatty acid desaturase; CPT-1: Carnitine palmitoyl transferase-1, SOD-1: Superoxide dismutase-1; GPx-4: Glutathione peroxidase-4; PPAR-a: Peroxidase proliferation activated receptor-a; CYP11A1: Cytochrome P450, family 11, subfamily A, polypeptide 1

$[42,46]$. Theoretically, alteration of secretions from the accessory sex gland may modify the environment of sperm, and subsequently affect sperm quality [47]. ACP are involved in the metabolism of spermatozoa via the hydrolysis of carbohydrates [48] and are associated with semen concentration [49]. Fructose is thought to be a major energy source for sperm movement, and low level of seminal fructose coincided with decreasing sperm motility and fertilization ability [50]. It has been reported that seminal plasma alpha-glucosidase activity reflects the functional state of the epididymis and has an important role in azoospermia $[29,30,51]$.

One of the most important factors contributing to poor semen quality has been reported to be oxidative stress [31]. Reports showed that oxidative stress is associated with fatty acid oxidation, which directly affects the survival of sperm $[52,53]$. In the current study, it was found that gene expression related to fatty acid metabolism in spermatozoa was altered by changes in dietary $n-6 / n-3$ ratios. Specifically, the mRNA expression of FAD6, CPT-1, PPAR- $\alpha$ and CYP11A1 were up-regulated in T2 boars, which may be associated with sperm fatty acid metabolism or antioxidant capacity. It is well known that PUFA can improve the antioxidant capacity of sperm $[10,54]$, which may further be related to a change of liver fatty acid composition and antioxidant capacity [52]. However, higher linoleic acid and arachidonic acid can cause the cascade reaction of lipid peroxidation and DNA damage of spermatozoa [53]. Lipid peroxides can be decomposed into MDA, and subsequently inhibit sperm mitochondrial function and enzyme activity, and affect sperm motility [54]. The present study showed that the mRNA levels of GPx-4 and SOD-1 were lower, and the GSH-Px enzyme activity in T2 treatment boars was higher, as compared to the $C$ group. Therefore, an $n-6 / n-3$ ratio of 1:1 may more effectively reduce exogenous oxidative damage in boar sperm, providing a more favorable environment for sperm survival. In contrast, a higher $n-3 / n-6$ ratio is not recommended in the diet of boars.

\section{Conclusion}

In summary, proper $n-6 / n-3$ fatty acid ratio in the diet of breeding boars enhanced the development of testis and accessory sex gland function, and improved sperm quality, which may be related to favorable hormone metabolism and antioxidant capacity. These findings suggest that a balanced dietary $n-6 / n-3$ PUFA ratio before sexual maturity plays an important role in breeding boars, and may also apply to humans and other species.

\section{Abbreviations \\ ACP: acid phosphatase; CPT-1: carnitine palmitoyl transferase-1; CYP11A1: cytochrome P450: family 11, subfamily A, polypeptide 1; FAD6: $\Delta^{6}$ - fatty acid desaturase; GSH-Px: glutathione peroxidase; MDA: malonaldehyde; $\mathrm{PGE}_{2}$ : prostaglandin E2; PPAR-a: peroxidase proliferation activated receptor- alpha; PUFA: polyunsaturated fatty acid(s); T: testosterone; T-AOC: total- Antioxidant capacity; T-SOD: total superoxide dismutase.}

\section{Competing interests}

The authors declare that we have no competing interests.

\section{Authors' contributions}

The authors' contributions are as follows: $Y L, X C$ and DW contributed to the study design and carried out the study; $X C$ and $B R ; S-Y X$ contributed to the data analysis and interpretation of data; JM, L-QC, Z-FF contributed to the data interpretation and manuscript preparation. C-MW, JL contributed to the sample analysis. All authors read and approved the final manuscript.

\section{Acknowledgements}

This research was supported by the Institute of Animal Nutrition of Sichuan Agricultural University. We thank Ms Kevin L. Fritsche for suggestion and editorial assistance. We are grateful to all the participators who participated in this study for their time and effort.

\section{Author details}

${ }^{1}$ Key Laboratory for Animal Disease Resistance Nutrition of the Ministry of Education of China, Institute of Animal Nutrition, Sichuan Agricultural University, Ya'an 625001, China. ²Division of Animal Sciences, University of Missouri, Columbia, MO 65211, USA.

Received: 12 September 2015 Accepted: 23 November 2015

Published online: 16 February 2016 


\section{References}

1. Ahluwalia B, Holman RT. Fatty acid composition of lipids of bull, boar, rabbit and human semen. J Reprod Fertil. 1969;18:431-7.

2. Johnson LA, Gerrits RJ, Young EP. The fatty acid composition of porcine spermatozoa phospholipids. Biol Reprod. 1969;1:330-4.

3. Maldjian A, Pizzi F, Gliozzi T, Cerolini S, Penny P, Noble R. Changes in sperm quality and lipid composition during cryopreservation of boar semen. Theriogenology. 2005:63:411-21.

4. Waterhouse KE, Hofmo PO, Tverdal A, Miller RR. Within and between breed differences in freezing tolerance and plasma membrane fatty acid composition of boar sperm. Reproduction. 2006;31:887-94.

5. Erickson MC. Chemistry and function of phospholipids. Food lipids, chemistry, nutrition and biochemistry. New York: Marcel Dekker Inc.; 1998, p. 41.

6. Gaczarzewicz D, Piasecka M, Udała J, Błaszczyk B, Laszczyńska M, Kram A. Oxidoreductive capability of boar sperm mitochondria in fresh semen and during their preservation in BTS extender. Reprod Biol. 2003;3:161-72.

7. Esmaeili V, Shahverdi AH, Moghadasian MH, Alizadeh AR. Dietary fatty acids affect semen quality: a review. Andrology. 2015;3:450-61.

8. Silva PF, Gadella BM. Detection of damage in mammalian sperm cells. Theriogenology. 2006;65:958-78.

9. Estienne MJ, Harper AF, Crawford RJ. Dietary supplementation with a source of omega-3 fatty acids increases sperm number and the duration of ejaculation in boars. Theriogenology. 2008;70:70-6.

10. Strzezek J, Fraser L, Kuklińska M, Dziekońska A, Lecewicz M. Effects of dietary supplementation with polyunsaturated fatty acids and antioxidants on biochmical characteristics of boar semen. Reproduction. 2004:4:271-87.

11. Yeste M, Barrera X, Coll D, Bonet $S$. The effects on boar sperm quality of dietary supplementation with omega-3 polyunsaturated fatty acids differ among porcine breeds. Theriogenology. 2011;76:184-96.

12. Castellano CA, Audet I, Bailey JL, Chouinard PY, Laforest JP, Matte JJ. Effect of dietary n-3 fatty acids (fish oils) on boar reproduction and semen quality. J Anim Sci. 2010;88:2346-55.

13. Safarinejad MR, Hosseini SY, Dadkhah F, Asgari MA. Relationship of omega-3 and omega- 6 fatty acids with semen characteristics, and antioxidant status of seminal plasma: Acomparison between fertile and infertile men. Clin Nutr. 2010;29:100-5.

14. Safarinejad MR, Safarinejad S. The roles of omega-3 and omega- 6 fatty acids in idiopathic male in fertility. Asian J Androl. 2012;14:514-5.

15. Golzar A, Cooper RG, Kamali MA, Hajbabaei A. The influence of inclusions of vitamin $\mathrm{E}$ and corn oil on semen traits of Japanese quail (coturnix coturnix japonica). Anim Reprod Sci. 2011;123:119-25.

16. Castellano CA, Audet I, Laforest JP, Matte JJ, Suh M. Fish oil diets alter the phospholipid balance, fatty acid composition, and steroid hormone concentrations in testes of adult pigs. Theriogenology. 2011;76:1134-45.

17. Rooke JA, Shao CC, Speake BK. Effects of feeding tuna oil on the lipid composition of pig spermatozoa and in vitro characteristics of semen. Reproduction. 2001;121:315-22.

18. Yan L, Bai XL, Fang ZF, Che LQ, Xu SY, Wu D. Effect of different dietary omega-3/omega-6 fatty acid ratios on reproduction in male rats. Lipids Health Dis. 2013;12:33.

19. Southern LL, Adeola O, Cornelis FM, National Research Council. Nutrient Requirements of Swine (NRC). 11th revised edition. Washington, DC, USA: National Academies Press; 2012.

20. Young LD, Leymaster KA, Lunstra DD. Genetic variation in testicular development and its relationship to female reproductive traits in swine. J Anim Sci. 1986:63:17-26.

21. Am-in N, Kirkwood RN, Techakumphu M, Tantasuparuk W. Lipid profiles of sperm and seminal plasma from boars having normal or low sperm motility. Theriogenology. 2011;75:897-903.

22. World Health Organization. Laboratory manual of the WHO for the examination of human semen and sperm-cervical mucus interaction. 2001

23. Kaeoket K, Donto S, Nualnoy P, Noiphinit J, Chanapiwat P. Effect of gammaoryzanol-enriched rice bran oil on quality of cryopreserved boar semen. J Vet Med Sci. 2012;74:1149-53

24. Sancho S, Pinart E, Briz M, Garcia-Gil N, Badia E, Bassols J, et al. Semen quality of post pubertal boars during increasing and decreasing natural photo periods. Theriogenology. 2004;62:1271-82.

25. Xu J, Gao H, Zhang L, Chen C, Yang W, Deng Q, et al. A combination of flaxseed oil and astaxanthin alleviates atherosclerosis risk factors in high fat diet fed rats. Lipids Health Dis. 2014;13:63.
26. Fan YY, Ran Q, Toyokuni S, Okazaki Y, Callaway ES, Lupton JR, et al. Dietary fish oil promotes colonic apoptosis and mitochondrial proton leak in oxidatively stressed mice. Cancer Prev Res. 2011;4:1267-74.

27. Elzanaty S, Malm J, Giwercman A. Duration of sexual abstinence: epididyma and accessory sex gland secretions and their relationship to sperm motility. Hum Reprod. 2005;20:221-5.

28. Anderson RA, Reddy JM, Oswald C, Zaneveld LJ. Enzymic determination of fructose in seminal plasma by initial rate analysis. Clin Chem. 1979;25:1780-2.

29. Elzanaty S, Richthoff J, Malm J, Giwercman A. The impact of epididymal and accessory sex gland function on sperm motility. Hum Reprod. 2002;17:2904-11.

30. Mahmoud AM, Geslevich J, Kint J, Depuydt C, Huysse L, Zalata A, et al. Seminal plasma a-glucosidase activity and male infertility. Hum Reprod. 1998;13:591-5.

31. Ibrahim SF, Osman K, Das S, Othman AM, Majid NA, Rahman MP. A study of the antioxidant effect of alpha lipoic acids on sperm quality. Clinics (Sao Paulo). 2008:63:545-50.

32. Swierstra EE. A comparison of regular ejaculation with sexual rest on semen characteristics and reproductive organ weights in young boars. J Anim Sci. 1974;39:575-81.

33. Ford JJ, Wise TH. Assessment of pubertal development of boars derived from ultrasonographic determination of testicular diameter. Theriogenology. $2011 ; 75: 241-7$

34. Cerolini S, Maldjian A, Pizzi F, Gliozzi TM. Changes in sperm quality and lipid composition during cryopreservation of boar semen. Reproduction. 2001;121:395-401.

35. Patterson E, Wall R, Fitzgerald GF, Ross RP, Stanton C. Health implications of high dietary omega-6 polyunsaturated Fatty acids. J Nutr Metab. 2012;2012: 539426.

36. Blesbois E, Douard V, Germain M, Boniface P, Pellet F. Effects of n-3 polyunsaturated dietary supplementation on the reproductive capacity of male turkeys. Theriogenology. 2004;61:537-49.

37. Daraji HJ, Mashadani HA, Hayani WK. Effect of n-3 and n-6 fatty acid supplemented diets on semen quality in japanese quail (coturnix coturnix japonica). Int J Poult Sci. 2010;9:656-63.

38. Blank C, Neumann MA, Makrides M, Gibson RA. Optimizing DHA levels in piglets by lowering the linoleic acid to a-linolenic acid ratio. J Lipid Res. 2002:43:1537-43.

39. Catalfo GE, Alaniz MJ, Marra CA. Dietary lipids modify redox homeostasis and steroidogenic status in rat testis. Nutrition. 2008:24:717-26.

40. Kumaresan A, Bujarbaruah KM, Kadirvel G, Khargharia G, Sarma RG, Goswam J, et al. Early sexual maturityin local boars of North eastern India:Age-related changes in testicular growth, epididymal sperm characteristics and peripheral testosterone levels. Theriogenology. 2011;75:687-95.

41. Berger T, McCarthy M, Pearl CA, Taras E, Roser JF, Conley A. Reducing endogenous estrogens during the neonatal and juvenile periods affects reproductive tract development and sperm production in postpuberal boars. Anim Reprod Sci. 2008;109:218-35.

42. Daghistani HI, Hamad AW, Abdel DM, Swaifi M, Abu ZM. Evaluation of serum testosterone, progesterone, seminal antisperm antibody, and fructose levels among jordanian males with a history of infertility. Biochem Res Int. 2010;1:1-8.

43. Wagner A, Claus R. The effects of postnatal FSH substitution on sertoli cell number and the sperm production capacity of the adult boar. Anim Reprod Sci. 2009:110:269-82.

44. Hunt CD, Johnson PE, Herbel J, Mullen LK. Effects of dietary zinc depletion on seminal volume and zinc loss, serum testosterone concentrations, and sperm morphology in young men. Am J Clin Nutr. 1992;56:148-57.

45. Attia YA, Kamel Kl. Semen quality, testosterone, seminal plasma biochemical and antioxidant profiles of rabbit bucks fed diets supplemented with different concentrations of soybean lecithin. Animal. 2012;6:824-33.

46. Patel A, Dixit SH, Patel MA, Shah PH. Study of semen acid and alkaline phosphatase in relation to sperm count and motility. SEAJCRR. 2013;1:112-21.

47. Buckett WM, Lewis DI. Fructose concentrations in seminal plasma from men with nonobstructive azoospermia. Arch Androl. 2002:48:23-7.

48. Zöpfgen A, Priem F, Sudhoff F, Jung K, Lenk S, Loening SA, et al. Relationship between semen quality and the seminal plasma components carnitine, alphaglucosidase, fructose, citrate and granulocyte elastase in infertile men compared with a normal population. Hum Reprod. 2000;15:840-5.

49. Fan $Y Y$, Zhan $Y$, Aukema HM, Davidson LA, Zhou L, Callaway $E$, et al. Proapoptotic effects of dietary ( $n-3)$ fatty acids are enhanced in colonocytes 
of manganese-dependent superoxide dismutase knockout mice. J Nutr. 2009;139:1328-32.

50. Wathes CD, Robert ED. Polyunsaturated fatty acids in male and female reproduction. Biol Reprod. 2007:77:190-201.

51. Kim SJ, Zhang Z, Saha A, Sarkar C, Zhao Z, Xu Y, et al. Omega-3 and omega-6 fatty acids suppress ER- and oxidative stress in cultured neurons and neuronal progenitor cells from mice lacking PPT1. Neurosci Lett. 2010;479:292-6.

52. Ruiz-Gutiérrez V, Vázquez CM, Santa-Maria C. Liver lipid composition and antioxidant enzyme activities of spontaneously hypertensive rats after ingestion of dietary fats (Fish, Olive and High-Oleic Sunflower Oils). Bio Sci Rep. 2001;21:271-85.

53. Aitken RJ. Free radicals, lipid peroxidation and sperm function. Reprod Fertil Dev. 1995;7:659-68.

54. Selley ML, Lacey MJ, Bartlett MR, Copeland CM, Ardlie NG. Content of significant amounts of a cytotoxic end product of lipid peroxidation inhuman semen. J Reprod Fertil. 1991;92:291.

Submit your next manuscript to BioMed Central and we will help you at every step:

- We accept pre-submission inquiries

- Our selector tool helps you to find the most relevant journal

- We provide round the clock customer support

- Convenient online submission

- Thorough peer review

- Inclusion in PubMed and all major indexing services

- Maximum visibility for your research

Submit your manuscript at www.biomedcentral.com/submit
Biomed Central 